Shamayim: Jurnal Teologi dan Pendidikan Kristiani

Volume 1, Nomor 1, 2020 (92-106)

http://hologos.college/ejournal/index.php/shamayim/index

\title{
Menerapkan Matius 5:13 Tentang Garam Dunia di Tengah Era Disrupsi
}

\author{
Yonatan Alex Arifianto \\ Sekolah Tinggi Teologi Sangkakala, Salatiga \\ arifianto.alex@sttsangkakala.ac.id \\ Reni Triposa, \\ Sekolah Tinggi Teologi Sangkakala, Salatiga \\ renitriposa@sttsangkakala.ac.id \\ Daniel Supriyadi \\ Sekolah Tinggi Teologi Sangkakala, Salatiga \\ danielsupriyadid544@gmail.com
}

\begin{abstract}
Spiritual growth to be a blessing and influence and impact on others cannot be separated from the challenges of life. And it is part of the believer's role to be able to color and make himself a useful person. Yet the church and the believers experienced divisions that created conflict and contention so that the church could not speak or give anything to a divided, corrupted world. With the background of the problem, the author uses a library research method with a descriptive quantitative approach. So the author concludes that the role of believers as the salt of the world in Matthew 5:13, in the midst of an era of disruption, is the first Christianity that does not become tasteless. Second, Christianity must function like salt and third, Christianity must glorify God in its life. By applying to all believers, the role of Christians as the salt of the earth has an impact.
\end{abstract}

Key words: Salt Of The World, Believers, The Role Of Christianity

\begin{abstract}
Abstrak
Pertumbuhan rohani untuk menjadi berkat dan pengaruh serta berdampak bagi sesama tidak lepas dari tantangan kehidupan. Dan hal itu sebagai bagian peran orang percaya untuk dapat mewarnai dan menjadikan dirinya sebagai orang yang berguna. Namun gereja dan orang percaya mengalami perpecahan yang menimbulkan konflik dan pertengkaran sehingga gereja tidak bisa berbicara atau memberikan apa-apa kepada dunia yang terpecah, rusak. Dengan latar belakang permasalahan, penulis menggunakan metode penelitian pustaka dengan pendekatan kuantitatif deskriptif. Maka penulis dengan mendapatkan kesimpulan bahwa peran orang percaya sebagai garam dunia dalam Matius
\end{abstract}


5: 13, ditengah era disrupsi adalah pertama kekristenan yang tidak menjadi tawar. Kedua Kekristenan harus berfungsi seperti garam dan yang ketiga, Kekristenan harus memuliakan Tuhan dalam hidupnya. Dengan mengaplikasikan bagi semua orang percaya peran orang kristen sebagai garam dunia yang berdampak.

Kata kunci: Garam Dunia, Orang Percaya, Peran Kekristenan

\section{Pendahuluan}

Yesus yang telah menyelamatkan dan membawa setiap pribadi menjadi berkat bagi sesama dengan melakukan pekerjaan-pekerjaan yang baik di semua aspek dan market place di kehidupan orang percaya. Terlebih orang percaya diharapkan dapat membawa dampak ada di semua lapisan masyarakat. Konsep ini meyakinkan orang percaya menjadi alat Tuhan untuk menerangi dunia dan memberikan rasa pada dunia seperti yang di inginkan Tuhan lewat penyataannya tentang garam dalam Matius 5:13, supaya dengan perbuatan-perbuatan baik yang berkenan kepada Tuhan dan sesuai dengan kehendak Allah. Namun dewasa ini banyak hal yang tidak maksimal untuk mencapai keinginan Tuhan sebab tiap-tiap gereja yang terdiri dari orang percaya mempunyai persoalan masingmasing. ${ }^{1}$

Lebih parahnya gereja mengalami perpecahan atau berpisah, perpecahan itu menimbulkan konflik dan pertengkaran sehingga gereja tidak bisa berbicara atau memberikan apa-apa kepada dunia yang terpecah, rusak, dan keras. Apalagi gereja terjerumus kepada hal yang tidak bermoral, tidak bisa mengatakan atau menyampaikan pesan apa-apa kepada dunia yang tidak bermoral. Gereja yang penuh korupsi, diskriminasi kasta, dan bentuk-bentuk lain penindasan sosial, etnis, atau gender, tidak memiliki apa pun untuk dikatakan kepada dunia yang penuh sesak dengan hal-hal seperti itu. ${ }^{2}$

Gereja tidak ada jawaban bagi dunia, terlebih gereja atau orang percaya menjadi tidak maksimal dalam kepanjangan tangan Tuhan untuk berdampak. Memang inti persoalan-persoalan kehidupan manusia di dalam gereja itu tak pernah bisa selesai, dari dulu sampai sekarang, baik di kota maupun di desa, selalu mempunyai persoalan. Tidak ada gereja tanpa persoalan. tidak ada jemaat yang tidak bermasalah. ${ }^{3}$ Namun hal ini tidak menjdi pembenaran untuk tidak menjadi berkat sebab esensi final orang percaya adalah menjadi terang dan garam bagi dunia yang semakin hari semakin jahat dan kasih yang semakin dingin. Dengan jelas di dalam rangkaian khotbah di bukit, Yesus memberikan penyatakan bahwa seorang Kristen adalah garam dan terang (Mat. 5:13-16). Kehadiran seorang Kristen sebagai garam dan terang dapat diartikan sebagai bukti untuk berdampak yang mentransformasikan dan memberi warna bagi lingkungan sekitarnya.

\footnotetext{
${ }^{1}$ Andi Yohanes, Berjumpa Dengan Dia Yang Bangkit (Jakarta: BPK Gunung Mulia, 2007), 37.

${ }^{2}$ Christopher J. H. Wright, Misi Umat Allah, (Jakarta: Literatur Perkantas, 2011), 116.

${ }^{3}$ Yohanes, Berjumpa Dengan Dia Yang Bangkit.
} 
Dalam bukunya karakter warga gereja, Gilbert Lumaindong mengatakan bahwa: Merasa kuatir dengan orang Kristen sebab banyak orang di gereja berlaku munafik, karena orang-orang munafik lebih senang berada dalam gereja. Justru orang di luar kalangan gereja lebih "jujur" daripada orang-orang di dalam Gereja, di dalam sel penjara, mereka para tahanan tahu pasti siapa dan apa yang telah dilakukan oleh rekan-rekan mereka di dalam penjara. Di rumah-rumah bordir atau pelacuran para pekerja seks komersial pun saling tahu apa yang rekan-rekan mereka lakukan di sana. Tetapi justru di dalam gereja, disuguhkan dengan drama sebab melihat banyak orang berlaku manis, baik tetapi belum tentu sama ketika mereka berada di luar. ${ }^{4}$ Tidak adanya integristas dalam menjalani kehidupan dan dedikasi dalam menjalankan kekristenan tidak dipungkiri permasalahan dalam pertumbuhan iman Kristen maupun pertumbuhan rohani menjadi terkendala dengan hadirnya persoalan dalam kehidupan orang percaya yang tidak luput juga dari perjuangan dan pergumulan iman. Di satu pihak hal itu memperkuat, atau memperkokoh dan menyemangati iman percayanya, tetapi di lain pihak, hal ini menjadi pesimis dan mengganggu kerohanian dan juga dapat menggoncangkan iman sehingga dapat saja mengakibatkan kebimbangan. ${ }^{5}$ Hal tersebut menimbulkan kekecewaan sehingga mempengaruhi hidupnya untuk melakukan hal yang tidak berkenan dihadapan Tuhan.

Dunia hari ini sedang menghadapi fenomena dan keadaan yang sangat cepat berubah di mana pergerakan dunia tidak lagi berjalan linear. Tatatan baru datang menggantikan tatanan lama yang sudah tidak sesuai dengan tuntutan era zaman sekarang. Disrupsi menginisiasi lahirnya model interaksi baru yang lebih inovatif dan masif. Cakupan perubahannya luas mulai dari dunia usaha, perbankan, transportasi, sosial kemasyarakatan, pendidikan hingga politik. Oleh sebab itu era ini melahirkan dua pilihan penting, berubah atau punah. ${ }^{6}$ Proses perubahan yang masif di hampir semua sektor mengarahkan individu kepada dua pilihan, pegang kendali atau dikuasai perubahan. ${ }^{7}$ dunia sedang berkembang ke arah yang berubah dengan cepat terutama khususnya dalam hal teknologi, terjadi begitu cepat bahkan perubahan tersebut jauh lebih pesat terjadi dibandingkan abad sebelumnya. ${ }^{8}$ Teknologi mengubah tatanan yang ada. ${ }^{9}$

Perubahan yang maju saat ini didorong oleh inovasi sains dan teknologi yang bisa mempengaruhi di dunia sosial yang menjadi tujuannya adalah sikap dan tindakan manusia dalam berkomunikasi dan terlebih mempengaruhi budaya dan norma dan agama. Negaranegara maju, yang selama ini menjadi pusat perkembangan ilmu pengetahuan dan

\footnotetext{
${ }^{4}$ Gilbert Lumoindong, Karakter Warga Gereja, (Jakarta: Light Publishing, 2010 ), 97.

${ }^{5}$ Roy D Tamaweol, "IMAN KRISTEN DAN GERAKAN KHARISMATIK," Jurnal Teologi Educatio Christi (2017).

${ }^{6}$ Khoiruddin Bashori, "Pendidikan Politik Di Era Disrupsi," Sukma: Jurnal Pendidikan (2018).

${ }^{7}$ Ajeng Wulansasi and Ahmad Aji Jauhari Ma'mun, "KEPEMIMPINAN PENDIDIKAN: MENGHADAPI DISRUPSI DAN VUCA DI MASA DEPAN," MANAGERE : Indonesian Journal of Educational Management 1 (2019): 51-75.

${ }^{8}$ Enggar Objantoro, "Religious Pluralism And Christian Responses," Evangelikal: Jurnal Teologi Injili dan Pembinaan Warga Jemaat (2018).

9 Wulansasi and Ma'mun, "KEPEMIMPINAN PENDIDIKAN: MENGHADAPI DISRUPSI DAN VUCA DI MASA DEPAN."
} 
teknologi, telah menyadari perubahan tersebut. Kondisi itu tentunya perlu disikapi juga pada kehidupan kerohanian orang percaya yang ditekankan dalam pergaulan dalam bermasyarakat. Sebab perubahan disruptif menumbangkan sistem yang berlaku yang sudah dikerjakan manusia hingga akhirnya terjadi perubahan mendasar tidak boleh diabaikan. Artinya, orang percaya pun tak lepas dari ancaman disrupted bila tidak segera melakukan perubahan dan menyesuaikan peranannya sebagai saksi Kristus. Faktanya banyak orang percaya yang egois akan keselamatannya pribadi dari pada peduli dengan orang lain dengan sibuk terhadap perubahan zaman teknologi ini.

Dari persoalan yang mendasari latar belakang penulisan tersebut menjadi pertanyaannya, bagaimanakah peran orang percaya sebagai garam dunia? karena Pokok utama tersebut adalah ketidakbergunaan sesuatu yang dikerjakan orang percaya dan berdampak bagi identitas kekristenan menjadi buruk bahkan dapat menjadi batu sandungan bagi orang yang belum percaya. Maka itu bila seseorang kristen tidak memenuhi maksud dan esensi kekristenan, ia berada di jalan yang menuju kesalahan. Seharusnya kekristenan adalah menjadi pribadi yang berkualitas dalam kerohanian dan dapat berdampak seperti perkataan Yesus bahwa orang Kristen harus menjadi garam dunia. Namun kalau hidupnya tidak menjadi garam dan memancarkan sinar terang, maka sesungguhnya keberadaan orang percaya sedang menuju kepada malapetaka. ${ }^{10}$ Untuk itu penulis mendeskripsikannya sebagai jawaban bagi gereja dan orang percaya masa kini.

\section{Metode Penelitian}

Untuk menjawab pertanyaan bagaimana peran orang percaya menerapkan Matius 5:13 sebagai garam dunia maka penulis menggunakan metode penelitian pustaka dengan pendekatan kualitatif deskriptif, ${ }^{11}$ yang menganalisi data-data studi peran orang percaya sebagai garam dunia yang ditemukan, dan hal tersebut diinventarisasi baik maknanya maupun konteksnya. Setelah terumuskan konsep pemaparan maka dilakukan dengan menjelaskan analisis teks dalam mencari makna, kemudian diuraikan secara singkat bagaimana garam dunia berperan. Dengan mengunakan Alkitab sebagai sumber primer dapat ditemukan ayat-ayat yang memuat kata-kata yang diinginkan oleh tema tersebut. Dan setiap kata yang berhubungan dengan peran orang percaya sebagai garam dunia ditelusuri dengan literature pustaka buku-buku terbaru dan terbitan jurnal untuk menambah penelitian pustaka ini. Dari makna literal maupun makna kontekstual, maka dapat disusun kajian peran orang percaya sebagai garam dunia dalam persepektif Matius 5:13 yang dapat dituangkan secara deskriptif.

${ }^{10}$ William Barclay, Pemahaman Alkitab Stiap Hari Injil Matius Pasal 1-10 (Jakarta: BPK Gunung Mulia, 2008), 203.

${ }^{11}$ Sonny Eli Zaluchu, "Strategi Penelitian Kualitatif Dan Kuantitatif Di Dalam Penelitian Agama," Evangelikal: Jurnal Teologi Injili dan Pembinaan Warga Jemaat 4, no. 1 (2020): 28-38. 


\section{Pembahasan dan Hasil}

Saat ini sedang popular istilah disrupsi (dari asal kata disrupt yang berarti mengacaukan; mengganggu. Disruption yang memiliki arti gangguan; kekacauan. sedangkan disruptive memiliki arti yang mengacaukan; yang mengganggu). ${ }^{12}$ Era disrupsi dalam buku Self Disruption karya Rhenald Kasali mengungkapkan bahwa disrupsi adalah perubahan yang terjadi sebagai akibat hadirnya masa depan ke masa kini. ${ }^{13}$ Perkembangan kemajuan teknologi yang sangat pesat beredar di kalangan masyarakat tentu memiliki dua sisi dampak positif maupun negatif bagi masyarakat secara keseluruhan. Dampak sisi positif yang didapat adalah masyarakat mendapatkan informasi yang up to date dengan cepat di berbagai bidang kehidupan manusia menggunakan sitem informasi dan teknologi yang jauh lebih maju. Sedangkan dampak sisi negatifnya, informasi yang disajikan tidak semuanya sesuai dengan nilai dan norma budaya suatu masyarakat. Daniel Ronda juga mengatakan bahwa: informasi dan pengetahuan yang dimiliki saat ini tidak tersaring lagi sehingga banyak bertebaran berita sampah, palsu (hoaks), pornografi, kekerasan di mana semuanya itu sudah tidak ada yang bisa menyaringnya dengan cara apapun lagi. ${ }^{14}$ Dan hal itu bisa mempengaruhi kehidupan kekristenan jika semua informasi yang tidak sesuai dengan nilai kekristenan itu terkomsumsi terus menerus bagi orang percaya sehingga untuk menjadi garam bagi orang lain tidak maksimal.

Di era perubahan ini kekeristenan akan berdampak menjadi garam bila ikut masuk dalam dunia perubahan secara cepat tersebut. Dimana orang percaya dalam pergaulannya menggunakan gadget yang terhubung dengan media sosial harus mencerminkan Kristus dalam hidupnya. Menjadi garam di era disrupsi seperti ini harus memberikan makna kehidupan yang selaras dengan Firman Tuhan dalam mengupayakan kehidupan, dan membawa pesan kebaikan dan kedamaian dalam setiap situasi dan kondisi dan yang terpenting menghidupi dan menjalani kerohanian yang nyata secara pribadi sesuai nilai dan aturan dalam kebenaran Firman Allah. Tantangan era informasi menjadi semacam penderitaan bila kerohanian dan pertumbuhan imannya tidak kokoh dalam membentengi informasi secara digital yang dapat mengubah prilaku manusia. Namun orang percaya diharap untuk berkaca dari sisi kebanaran Alkitab sebagai dasar pemahaman (back to bible) yang benar tentang karya Yesus sebagai penyelamat memberi pendewasaan dalam iman dan kerohanian. ${ }^{15}$ Sehingga situasi apapun dalam perubahan baik teknologi dan konsep antropologi dalam masyarakat sosial tidak mempengaruhi iman dan kerohaniannya.

Orang percaya harus menjaga hidupnya dan terlebih dalam sikapnya sebagai bagian dari rencana Tuhan untuk menjadi berkat harus meyakini sepenuhnya bahwa Firman Allah yang tertulis dalam Alkitab, dengan jelas mengajarkan kebenaran tentang manusia, jalan

${ }^{12}$ Lia Muliawaty, "PELUANG DAN TANTANGAN SUMBER DAYA MANUSIA DI ERA DISRUPSI," Kebijakan : Jurnal Ilmu Administrasi (2019).

${ }^{13}$ Rhenald Kasali, Self Disruption (Jakarta: Mizan Anggota IKAPI, 2018), 109.

${ }^{14}$ Daniel Ronda, "Kepemimpinan Kristen Di Era Disrupsi Teknologi," Evangelikal: Jurnal Teologi Injili dan Pembinaan Warga Jemaat (2019).

15 Erman S. Saragih, "SOTERIOLOGI HYPERGRACE DALAM PERSPEKTIF TEOLOGI MARTIN LUTHER DAN ALKITAB,” Teologi Cultivation (2017). 
keselamatan, dan kehidupan Kristen sebagai ajaran yang murni. ${ }^{16}$ Dapat menjadi bagian dari komunitas orang percaya, atau menjadi bagian dari tubuh Kristus dan terlebih sejatinya orang percaya dapat memberikan sumbangan pemikiran-pemikiran yang berdasarkan iman Kristen. ${ }^{17}$ Sehingga hal itu mempengaruhi kekristenan untuk terus menjadi berkat dalam setiap aspek kehidupan. Pernyataan Yesus dalam Matius 5: 13 memberikan pesan bahwa tanpa adanya kekristenan yang membawa dampak baik maka akan dianggap sebagi garam yang menjadi tawar. Garam bukanlah substansi yang bersifat diam atau hanya bertahan saja. Garam akan segera menyebar memengaruhi seluruh tempat tersebut bila ia ditaburkan. ${ }^{18}$ Garam merupakan suatu kekuatan yang sangat memberi pengaruh. Jadi, orang percaya yang disebut garam dan terang dunia sudah sewajarnya memberikan pengaruh semacam itu bukan sekadar bertahan di tengah-tengah kegelapan dan kebusukan dunia ini. ${ }^{19}$ Maupun ditengah era perubahan zaman maupun era disrupsi saat ini.

\section{Analisis Matius 5:13}

"Kamu adalah garam dunia. Jika garam itu menjadi tawar, dengan apakah ia diasinkan? Tidak ada lagi gunanya selain dibuang dan diinjak orang. Matius 5:13.

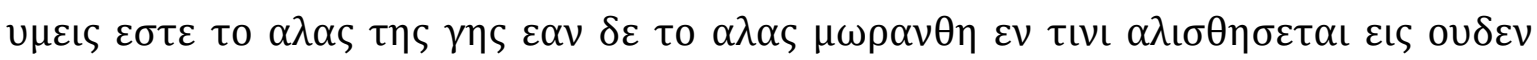

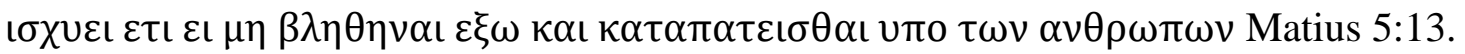

humeis (kamu) este (adalah) to halas (garam) tês gês (dunia) ean (jika) de (tetapi) to halas (garam) môranthê (menjadi tawar) en (dengan) tini (apakah) alisthêsetai (ia dijadikan asin/ ia digarami) eis (karena) ouden (sama sekali tidak) iskhuei (ia berguna) eti ei (kecuali) mê blêthênai (dibuang) exô (keluar) kai (dan) katapateisthai (diinjak-injak) hupo (oleh) tôn anthrôpôn (orang-orang). Matius 5:13.

Dengan mengkaji teks Matius 5: 13 maka untuk tetap menjadi dampak dan menerapkan identitas kekristenan menjadi garam orang percaya memiliki ciri yaitu:

\section{Kekristenan Yang Tidak menjadi Tawar}

Pernyataan Yesus dalam Matius 5: 13 ini berkaitan juga dengan apa yang dinyatakan Yesus tentang hendaknya menjadi gararn dunia atau terang dunia, melainkan "kamu adalah garam dunia dan terang dunia". Kata "adalah" menunjuk being, suatu identifikasi, dan bukan becoming atau proses menjadi. ${ }^{20}$ Maka itu dari panggilan yang ditetapkan Yesus dan yang diutus sebagai garam dan terang dunia ini, menjadikan orang percaya sejatinya

${ }^{16}$ Yohanes Adrie Hartopo, "Doktrin Sola Scriptura ," Veritas: Jurnal Teologi dan Pelayanan (2002).

${ }^{17}$ Rantung Djoys Anneke, Pendidikan Agama Kristen Dalam Kehidupan Masyarakat Majemuk (Yogyakarta: Lintang Rasi Aksara Books, 2017).

${ }^{18}$ Tim Penulis KAMBIUM, Berbuah Dalam Kristus: Pemuridan Melalui Waktu Teduh (Yogyakarta: Yayasan Gloria, 2015), 44.

${ }^{19}$ Tim Penulis KAMBIUM, Berbuah Dalam Kristus: Pemuridan Melalui Waktu Teduh.

${ }^{20}$ Emanuel Martasudjita, Sakramen-Sakramen Gereja: Tinjuan Teol, Liturgis, Pastoral (Yogyakarta: penerbit Kanisius, 2003), 87. 
menemukan makna hidup gereja sebagai berkat dan kesaksian bagi dunia, yang pada dasarnya tentu menampakkan keselamatan Allah dalam Yesus Kristus kepada dunia. ${ }^{21} \mathrm{Hal}$ inilah yang diharapkan oleh Yesus sebab panggilan Tuhan dalam keselamatan harus disertai hidup dalam ketaatan Firman Tuhan sehingga dapat membawa dampak yang baik bagi sesama. Sebab Allah memberikan FirmanNya agar manusia bisa belajar atau memahami rencana-rencana-Nya, maupun sudut pandang-Nya terkait kehidupan manusia maupun berbagai aspek pemikiran yang seharusnya dimiliki oleh manusia supaya manusia dapat hidup berkenan dan menjadi terang dan garam bagi sesama. ${ }^{22}$ Selaras dengan hal tersebut Sairwona mengungkapkan bahwa: Kekristenan yang diterapkan dan ditujukan dalam segala aspek untuk membangun kehidupan rohani dalam pengenalan akan Tuhan yang benar, dan membawa iman untuk menghadapi tantangan dan dapat mempertahankannya namun terlebih juga membawa orang percaya untuk menjadi terang dan garam (Matius 5 : 13-14). Maka dari pada itu sebagai warga gereja dan umat Allah dalam hal ini gembala diharapkan mampu membawa orang percaya kepada pertumbuhan rohani dalam iman Kristen. Pentingnya pertumbuhan iman jemaat sebagai kualitas persekutuan jemaat secara pribadi dengan Kristus sebagai kepala gereja dan kualitas persekutuan jemaat dengan sesamanya. Jadi pertumbuhan iman memiliki dimensi vertikal sebagai sumber pertumbuhan iman secara pribadi dan dimensi horizontal sebagai sumber kesaksian kepada sesama. ${ }^{23}$ Dan terlebih menjadi pribadi yang mencerminkan Kristus dan menjadi suara kebenaran pada zamannya. ${ }^{24}$

Oleh karena itu kekristenan diharapkan untuk terus bertumbuh dan berkembang dalam kerohanian supaya tidak menjadi Kristen yang tawar. Yesus dalam pengajarannya tentang garam Yesus tidak mau membicarakannya secara ilmiah. Yesus memberi kepada para muridNya suatu pengetahuan spiritual, kebijaksanaan, "jalan hidup", supaya mereka mempertahankan mutu dunia ini. Mutu itu tidak dapat dipertahankan oleh pimpinan negara atau bangsa saja. Demikian pula tidak oleh pimpinan gereja saja. Padahal banyak orang menjadi anggota gereja, tetapi seolah-olah atau memang nyata-nyata tidak berfungsi sebagai bagian integralnya. ${ }^{25}$ Ironis sekali jika kekristenan tidak berdampak atau berfungsi maka hal sebagai garam dan terang dunia tidak dijalankan dengan sungguh oleh orang percaya. Matthew Hendry Mengungkapakan sebagai orang-orang Kristen yang merosot akhlaknya, yang lebih memilih meninggalkan jalan kesalehan daripada harus melepaskan apa yang mereka miliki di dunia ini, dan yang tentu saja kemudian hidup menurut nafsu duniawi, dan sama sekali tidak mempunyai roh kristiani lagi, adalah seperti garam yang menjadi tawar, yang oleh para ahli kimia disebut caput mortuum, garam yang kadar keasinannya sudah terkikis habis. Garam seperti ini merupakan barang yang paling tidak

\footnotetext{
${ }^{21}$ Martasudjita, Sakramen-Sakramen Gereja: Tinjuan Teol, Liturgis, Pastoral.

${ }^{22}$ Kosma Manurung, "Taurat Dan Nubuat Palsu: Kajian Sudut Pandang Taurat Terhadap Nubuat Palsu," Jurnal Teologi Berita Hidup (2020).

${ }^{23}$ Wellem Sairwona, "KAJIAN TEOLOGIS PENYAMPAIAN FIRMAN TUHAN DAN PENGARUHNYA BAGI PERTUMBUHAN IMAN JEMAAT," Jurnal Pendidikan Agama Kristen (2017).

${ }^{24}$ Kosma Manurung, “Ketubim Dan Nubuat,” Pengarah: Jurnal Teologi Kristen (2020).

${ }^{25}$ Stefan Leks, Tafsir Injil Matius (Yogyakarta: penerbit Kanisius, 2003), 132.
} 
berguna dan paling tidak berharga di dunia. Tidak ada lagi nilai di dalamnya, tidak ada gunanya lagi untuk disimpan. ${ }^{26}$ Nilai esensinya bahwa Yesus menyuruh mereka waspada terhadap kemurtadan dan kemerosotan dalam semangat serta tingkah laku kristiani yang sejati, sebab ini akan membuat mereka tidak berguna sama sekali (Lukas. 34-35). Dan jika sudah terjadi bahwa perbuatan atau tingkah laku kekristenan tidak berdampak, dan menjadi batu sandungan serta mempermalukan kekristenan terlebih nama Tuhan maka orange tersebut dapat disamakan dengan garam yang kehilangan rasa sehingga membawa pada kesia-siaan. Seperti yang diungkapkan oleh Stefan Leks untuk menjadi perenungan akan akibat ketidak bergunaan garam, dengan apakah ia diasinkan (Matius 5:13). Dengan cara lain, kalimat ini dapat diungkapkan begini, "Bagaimana ia dapat menjadi garam lagi?". atau, "Bagaimana memulihkan khasiatnya yang khas?" 27 hal ini berarti kehilangan identitas jati diri kekristenannya. Menurut Suster Jeanne d'Arc penulis matius menggunakan kata Yunani moraine atau môranthê. Dalam bahasa Aramea, kata ini dapat berarti "kehilangan akal sehat: menjadi sinting atau tak karuan " dan "kehilangan rasa, mengakibatkan menjadi tawar. Artinya bahwa pengikut Kristus dapat kehilangan kebijaksanaan yang seharusnya dimilikinya. ${ }^{28}$ Kata kerja di dalam Matius 5:13 dan Lukas 14:34 untuk kata "kehilangan keasinannya" adalah moreinein, yang di dalam arti aktif memiliki arti utama "menyebabkan kebodohan" dan di dalam arti pasif mempunyai arti "menjadi bodoh.

Garam itu tidak dapat dipulihkan lagi: Dengan apakah ia diasinkan? Pasti tidak bisa. Ini menunjukkan bahwa sangatlah sulit, bahkan hampir mustahil, untuk mempertobatkan kembali orang yang sudah murtad (Ibrani. 6:4-6). Jika Kekristenan tidak dapat menyembuhkan manusia dari nafsu duniawinya, jika obat itu sudah dicoba namun sia-sia, maka mereka sudah tidak bisa disembuhkan lagi. ${ }^{29}$ Dan hal ini berakibat fatal dan menjadi sebuah ironi pertanggung jawaban bagi orang yang sudah menerima keselamatan tetapi tidak menjadikan dirinya berkat tetapi malah menjadi lawan dari Allah. Akibat tawar yang tidak digunakan orang maka garam akan dicampakan. Tidak adalagi gunanya secara harfiah berarti: ia tidak berguna untuk apa pun lagi. Kristal-kristal kecil yang tampak seperti gararn, tetapi tidak asin lagi, memang tidak dapat dipakai untuk apa-apa. ${ }^{30}$ Matthew Hendry menyebutkan bahwa garam itu dicampakkan sebagai penegasan orang membuangnya saja, seperti barang yang sudah tidak diperlukan lagi. Orang-orang munafik yang memalukan ini harus dikeluarkan dari antara jemaat, bukan hanya karena mereka telah menyia-nyiakan kehormatan dan keistimewaan yang telah mereka terima sebagai anggota jemaat, melainkan juga karena ada bahaya orang lain akan tertular oleh mereka. ${ }^{31}$

26 Henry's Matthew, "Matthew Henry Commentary On Whole Bible," 2002, https://www.biblestudytools.com/commentaries/matthew-henry-complete/Lukas/2.html.

${ }^{27}$ Leks, Tafsir Injil Matius.

${ }^{28}$ Ibid.

${ }^{29}$ Henry’s Matthew, "Matthew Henry Commentary On Whole Bible."

${ }^{30}$ Leks, Tafsir Injil Matius.

${ }^{31}$ Henry's Matthew, "Matthew Henry Commentary On Whole Bible." 


\section{Kekristenan Harus Berfungsi seperti garam}

Di zaman dulu garam merupakan barang yang sangat berharga. Orang Yunani bahkan menganggap garam itu ilahi (theion). Ada juga ungkapan Latin yang dipakai oleh orang Romawi. "Tidak ada sesuatu yang lebih berguna daripada matahari dan garam. ${ }^{32}$ Garam murni tidak pernah menjadi tawar. Tetapi di zaman kuno, garam (yang biasanya diambil dari Laut Mati) pada umumnya tidak murni secara kimia. sehingga khasiatnya dapat hilang, antara lain karena kelembaban tingkat tinggi. Yang tampak sebagai garam, dalam kenyataannya bukan garam seperti diharapkan lagi. ${ }^{33}$ Selaras dengan hal tersebut Homer A. Kent menjelaskan penafsirannya mengenai "garam" dan "terang" dalam Matius 5:13-16, yaitu: Garam. Pengawet makanan yang biasa, sering kali dipakai secara simbolis. Orang percaya merupakan penahan dari kerusakan dunia. Orang yang tidak percaya sering kali terlindung dari perbuatan kejahatan karena ada kesadaran moral yang dapat ditelusuri dari pengaruh Kristen. Sekalipun demikian, ilustrasi Kristus mungkin hanya kiasan saja untuk menunjukkan keganjilan dari seorang percaya yang tidak berguna. ${ }^{34}$ Namun dalam perintahNya Yesus sangat menekankan bahwa orang percaya harus menjadi garam.

Kata "garam" ditulis dalam bahasa Yunani "halas". Kata itu memiliki beberapa arti, yaitu pemberi rasa pada makanan, dipakai untuk menggemburkan tanah, sebagai bahan pengawet makanan dari kebusukan. Dari arti di atas, kita dapat menyimpulkan bahwa menjadi garam dunia berarti menjadi berkat dengan tindakan dan segala perbuatan termasuk dalam perkataan. Tidak berbeda dengan pandangan di atas, R.E. Nixon, dalam Tafsiran Alkitab Masa Kini, juga menjelaskan bahwa: Garam sangat berguna untuk mengawetkan. Bagi rabi garam berarti hikmat (Kolose 4:6). Hidup dan perkataan yang bijaksana dari murid-murid akan mempengaruhi masyarakat. ${ }^{35}$ Dan yang mengesankan garam tidak pernah menghancurkan apa yang harus diawetkannya, dan sekaligus mencegah terhadap pembusukan. Dengan nilai tersebut sejatinya Yesus mengajarkan serupa dengan garam, para pengikut Yesus tidak boleh menghancurkan apa pun di dunia yang sudah baik. Mereka justru harus berusaha supaya yang baik di dunia jangan mengalami proses pembusukan. Hal ini dapat mereka lakukan bila mereka berperan sebagai saksi dalam arti setia kepada panggilannya yang dapat dirumuskan adalah, "Mempertahankan yang baik, lalu memurnikannya lebih lanjut. ${ }^{36}$

Pada masa hidup Yesus garam selalu dihubungkan dengan 3 macam hal yaitu: Satu, garam selalu dihubungkan dengan kemurnian dan originalitas. Hal itu dapat di mengerti sebab garam berpartikel dan berwarna putih mengkilap dan jernih. Orang Romawi menganggap garam sebagai benda yang paling bersih dan jernih, karena ia berasal dari benda yang juga paling bersih dan jernih, yaitu matahari dan laut. Di zaman dulu garam

\footnotetext{
${ }^{32}$ Barclay, Pemahaman Alkitab Stiap Hari Injil Matius Pasal 1-10.

${ }^{33}$ Leks, Tafsir Injil Matius.

34 Ibid.

${ }^{35}$ R.E. Nixon, Matius Dalam Tafsiran Alkitab Masa Kini, ed. H.P. Nasution, Voleme 3. (Jakarta: Yayasan Komunikasi Bina Kasih/OMF, 1999), 71.

${ }^{36}$ Leks, Tafsir Injil Matius.
} 
merupakan korban yang paling disukai dan paling berharga bagi para dewa. Garam juga dipakai sebagai campuran korban yang dipersembahkan oleh orang Yahudi kepada Allah. Jadi kalau orang Kristen harus menjadi garam dunia maka ia harus menjadi contoh kesucian dan kemurnian. ${ }^{37}$ Menjadi garam memang kiasan yang tepat untuk memperlihatkan efektifitas dan kegunaan orang percaya bagi dunia ini. ${ }^{38}$ Dan menjadi pribadi orang percaya yang seharusnya menunjukkan berbagai keuntungan yang bisa membuat kehidupan di dunia ini lebih bermanfaat dan iman menjadi lebih kuat. ${ }^{39}$

Dua, di dunia kuno garam merupakan bahan pengawet yang umum digunakan dan banyak dipakai orang. Garam itu dipakai untuk mengawetkan agar benda-benda tidak rusak, dan juga untuk menjaga agar pantai tetap bersih. Plutarkh mengatakan bahwa daging sebenarnya adalah tubuh yang mati atau bagian dari tubuh yang mati, dan kalau dibiarkan akan mati rusak. Tetapi garam mengawetkan dan memelihara daging tersebut sehingga tetap segar. Karena itu garam adalah seperti jiwa yang dimasukkan ke dalam tubuh yang mati. ${ }^{40}$ Jadi garam bisa mengawetkan dan menghindarkan segala sesuatu dari kerusakan. Kalau orang Kristen harus menjadi garam dunia, maka ia harus mempunyai semacam pengaruh antiseptis terhadap hidup ini. Dan seharusnya yang terjadi dalam orang-orang Kristen yang baik, terutama hamba-hamba Tuhan yang baik (Mat. 5:13), adalah garam dunia, dan garam ini memang baik serta sangat berguna. Dengan pengajaran dan teladan mereka, orang-orang Kristen memberikan penyedap rasa kepada semua orang yang bergaul dengan mereka, mencegah mereka dari kebusukan, serta menyegarkan dan menyedapkan mereka. ${ }^{41}$ Murid-murid dahulu dan masa sekarang yang disebut sebagi orang percaya kepada Yesus diharapkan untuk menambah kualitas dari eksistensi manusia dan mengawetkannya dari kehancuran. ${ }^{42}$

Tiga tugas dan makna yang paling besar dan menyolok dari garam ialah bahwa garam memberikan rasa tertentu kepada banyak hal. Makanan tanpa garam akan merupakan sesuatu yang hambar, bahkan memuakkan. Kekristenan adalah sama dengan garam. Kalau garam merupakan bumbu terhadap masakan, maka kekristenan adalah bumbu yang menyedapkan dan mengenakkan hidup. Kekristenan memberikan cita rasa dan keharuman kepada kehidupan. Kekristenan memberikan makna yang baru dan baik kepada hidup manusia. ${ }^{43}$ Alkitab juga mengajarkan tentang peritiwa Istri Lot yang menjadi tiang garam akibat ketidaktaatannya kepada Tuhan seperti yang diungkapkan oleh Witness Lee bahwa: Istri Lot menjadi tiang garam karena dia menoleh ke Sodom seakan-akan

${ }^{37}$ Barclay, Pemahaman Alkitab Stiap Hari Injil Matius Pasal 1-10.

${ }^{38}$ Emmanuel Gerrit Singgih, Mengantisipasi Masa Depan: Berteologi Dalam Konteks Di Awal Milenium III (Jakarta: BPK Gunung Mulia, 2004), 290.

${ }^{39}$ Paul F. Knitter, Pengantar Teologi Agama-Agama (Yogyakarta: penerbit Kanisius, 2012), ix.

${ }^{40}$ Barclay, Pemahaman Alkitab Stiap Hari Injil Matius Pasal 1-10.

${ }^{41}$ Henry's Matthew, "Matthew Henry Commentary On Whole Bible."

${ }^{42}$ Dianne Bergant and Robert J. Karris, Tafsir Alkitab Perjanjian Baru (Yogyakarta: kanisius, 2002), 41.

${ }^{43}$ Barclay, Pemahaman Alkitab Stiap Hari Injil Matius Pasal 1-10. 
segan meninggalkannya. Pandangan yang demikian menunjukkan bahwa dia mengasihi dan menyanjung kekayaan dunia yang jahat yang akan dihakimi dan dimusnahkan oleh Allah. Dia diselamatkan dari Sodom, tetapi dia tidak sampai pada tempat aman yang dicapai Oleh Lot (Kej 19:15-30). Dia tidak binasa; juga tidak sepenuhnya diselamatkan. Seperti garam yang menjadi tawar (Luk. 14:34-35), dia ditinggalkan di tempat yang memalukan. Ini merupakan suatu peringatan yang serius kepada kaum beriman yang mengasihi dunia. ${ }^{44}$ Selaras dengan hal tersebut Nehemia Mimery mengatakan bahwa hal yang menyedihkan adalah adanya orang-orang percaya yang begitu tidak beretika moral yang baik dalam hidup mereka dan dengan demikian, mereka ini telah menjadi sandungan bagi orang-orang yang belum mengenal Kristus dan mereka tidak berkenan kepada Allah dan tidak menghormati Kristus dan Injil-Nya. ${ }^{45}$

\section{Kekristenan harus memuliakan Tuhan dalam Hidupnya}

Dengan menjadi garam dunia yang selaras dengan perkataanNya, Yesus hendak memberikan pujian serta penghargaan yang terbesar yang dapat diberikanNya kepada setiap orang. Sebab Ia ingin menyatakan dampak yang besar menjadi kesaksian dan peranan penting yang menentukan dari seseorang di dalam masyarakat. Bila hal itu terjadi ada predikat yang diberikan yaitu pribadi yang memenuhi penggilan Tuhan "Orang yang seperti itu adalah garam dunia." Sebab orang percaya atau kekristenan harus sesuai dengan panggilannya yang seharusnya dapat membawa dampak dan untuk tidak ikut serta melakukan perbuatan-perbuatan yang merendahkan kekristenan. ${ }^{46}$ Terlebih perbuatan dengan hal-hal yang tidak mempermuliakan Tuhan, harus dijauhkan dalam kehidupan orang percaya baik secara kehidupan yang dijalani dengan nyata maupun kehidupan dengan yang dikomunikasikan dalam media sosial tetap harus menjadi berkat. Karena orang percaya yang tidak memiliki ciri utama dari gambaran gereja sebagai keluarga Allah untuk menjadi berkat bagi sesama. Dianggap gagal sebagai manusia yang berdampak. Oleh karena itu sebagai bagian dari Tubuh Kristus yang adalah satu kesatuan iman didalam nama Tuhan wajib melakukan Kehendak Allah. ${ }^{47}$

Peran penting gembala, para pemimpin gereja adalah orang yang bertanggung jawab langsung kepada Allah, dan dapat menjadi teladan serta setia kepada pelayanan sebagai bagian untuk mendidik orang percaya dapat melakukan hal yang sama menjadi pribadi yang berdampak juga ditengah kehidupan bermasyarakat. Karena dalam panggilan sebagai pemimpin jemaat, gembala sidang atau penilik jemaat adalah panggilan untuk

${ }^{44}$ Witness Lee, Pelajaran Hayat Lukas (2) (Surabaya: Yayasan Perpustakaan Injil Indonesia (Yasperin), 2019).

${ }^{45}$ Nehemia Mimery, Komentar Praktis Injil Sinoptik (Jakarta: Mimery Press, 1999), 92.

${ }^{46}$ Makmur Halim, Model-Model Penginjilan Yesus: Suatu Penerapan Masa Kini (Malang: gandum mas, 2003), 539.

${ }^{47}$ Rijnardus A. van Kooij, Sri Agus Patnaningsih, and Yam'ah Tsalatsa, Menguak Fakta, Manata Karya Nyata”: Sumbangan Teologi Praktis Dalam Pencarian Model Pembangunan Jemaat Kontekstual (Jakarta: BPK Gunung Mulia, 2007), 108-113. 
melakukan pekerjaan yang indah. ${ }^{48}$ Para pemimpin sejatinya yang dapat mengajarkan kepada orang percaya untuk melakukan kehendak Tuhan dengan pengajaran yang Alkitabiah. Sebab yang perlu diperhatikan bahwa orang Kristen di Indonesia tidak hidup sendirian, melainkan bersama yang lain dalam sebuah masyarakat keagamaan yang bersifat majemuk. Ia harus hidup menghayati imannya di tengah mereka yang beragama lain, ${ }^{49}$ supaya menjadi berkat bagi sesama. Sebab dengan apa yang dilakukan itu menjadi bentuk ibadah yang benar-benar sesuai dengan apa yang dikehendaki oleh Tuhan dan sekaligus menyenangkan hati Tuhan. ${ }^{50}$ walaupun berkomunikasi dalam dunia daring dan menggunakan media sosial tetap berprilaku yang baik yang mencerminkan Yesus yang harus dikedepankan.

Tentu saja apa pun yang dialami dan dihadapi dalam perjalanan hidup bergereja dan sebagai orang percaya justru diminta tetap setia dalam iman kepada Tuhan Allah di dalam Yesus Kristus Juruselamat dalam bimbingan Roh Kudus, sekaligus tetap melayani dengan penuh kasih kepada sesama manusia. ${ }^{51}$ Dalam Lukas 14:35 Yesus mengakhiri perkataanNya di sini dengan suatu panggilan kepada semua orang untuk memperhatikan masalah ini baik-baik, dan untuk memberi prioritas apa yang telah diperingatkan-Nya: Siapa mempunyai telinga untuk mendengar, hendaklah ia mendengar. Nah, dengan cara apa lagi indra pendengaran kita ini dapat digunakan dengan lebih baik selain untuk mendengarkan firman Kristus, terutama untuk mendengarkan peringatan-peringatan-Nya kepada kita akan bahaya yang dapat membawa kita kepada kemurtadan, dan akan bahaya yang dapat menyusahkan kita sendiri karena kemurtadan ${ }^{52}$

Maka itu sebagai orang percaya untuk tetap mengandalkan pimpinan Tuhan melalui pertolongan Roh kudus. Yonatan Alex Arifianto dan Asih Sumiwi Rachmani mengungkapkan bahwa: Kehidupan yang sejalan dengan pekerjaan Roh Kudus sebagai tujuan orang percaya menjalani hidup dengan cara yang diharapkan Yesus yaitu hidup dalam Firman Tuhan dan merdeka dari segala ikatan dosa dan kutuk. Hal itu sangat memuliakan Tuhan dengan menghasilkan kembali karakter Kristus dalam diri orang-orang percaya. ${ }^{53}$ Schumann menyampaikan pandangannya, bahwa: manusia yang dipanggil Allah dan dikaruniai Roh Kudus bukan hanya diselamatkan dan dibenarkan untuk diri sendiri,

${ }^{48}$ Christine Fuceria Ginting, "Konsep Kepemimpinan Penggembalaan Berdasarkan 1 Timotius Dan Aplikasinya Terhadap Pertumbuhan Rohani Jemaat," PNEUSTOS: Jurnal Teologi Pantekosta (2018).

${ }^{49}$ Emanuel Gerrit Singgih, Bergereja, Berteologi Dan Bermasyarakat (Yogyakarta: Taman Pustaka Kristen, 2007), 196.

50 Firman Panjaitan and Marthin Steven Lumingkewas, "Ibadah Jemaat Kristen Kontemporer Abad 21 Dan Tinjauan Kritis-Liturgis," FIDEI: Jurnal Teologi Sistematika dan Praktika (2019).

${ }^{51}$ Tamaweol, "IMAN KRISTEN DAN GERAKAN KHARISMATIK."

52 Henry's Matthew, "Matthew Henry Commentary On Whole Bible," 2002, https://www.biblestudytools.com/commentaries/matthew-henry-complete/Lukas/2.html.

${ }^{53}$ Yonatan Alex Arifianto and Asih Sumiwi Rachmani, "Peran Roh Kudus Dalam Menuntun Orang Percaya Kepada Seluruh Kebenaran Berdasarkan Yohanes 16: 13," Jurnal Diegesis 3, no. 1 (2020): 1-12. 
melainkan juga diberi kemampuan untuk menjadi manusia yang benar di tengah-tengah ciptaan ini sebagai makhluk yang dalam banyak hal hidup terikat atau bersekutu dengan makhluk lainnya. ${ }^{54}$

Ungkapan garam yang kehilangan identitasnya tidak melekat kepada orang percaya. Karena Garam yang tidak ada gunanya lagi, tidak cocok baik untuk tanah maupun untuk pupuk, dan juga tidak akan ada manfaatnya jika dibuang di antara kotoran sampah sampai membusuk, karena tidak ada lagi yang bisa didapat darinya. Orang yang mengaku beragama namun pikiran dan tingkah lakunya rusak hal itulah diumpamakan orang yang tidak berdampak namun menjadi batu sandungan bagi orang lain. Dan menjadi miris bila orang yang tersebut jika membicarakan hal-hal tentang Allah, yang sedikit banyak diketahuinya, ia melakukannya dengan begitu canggung sehingga tidak ada orang yang dapat dibangun olehnya. Ini seperti amsal di mulut orang bebal. ${ }^{55}$ Sebab itu diperlukan hikmat yang menjadi unsur penting dan mendasar dalam keberhasilan seseorang mengaktualisasi panggilan hidupnya,${ }^{56}$ untuk menjadi garam bagi dunia

\section{Kesimpulan}

Menjadi garam dunia adalah tugas penting, sekaligus sebagai gaya hidup orang percaya dalam menjalani kehidupan kekristenannya. Yesus memiliki tujuan dan maksud yang kekal dalam esensi pennyataanNya sehingga perlu disikapi dan diterapkan dalam iman orang percaya untuk menjadi pelaku firman sebab jika orang percaya melakukan perbuatannya atau tingkah laku kekristenan yang tidak berdampak, menjadi batu sandungan serta mempermalukan kekristenan terlebih mempermalukan nama Tuhan maka orang tersebut dapat disamakan dengan garam yang kehilangan rasa sehingga membawa pada kesia-siaan.

Yang menjadi kesimpulan dalam peran orang percaya menerapkan Matius 5: 13 tentang garam di tengah era disrupsi adalah yang pertama adalah kekristenan yang tidak menjadi tawar. Kedua Kekristenan harus berfungsi seperti garam dan yang ketiga, Kekristenan harus memuliakan Tuhan dalam hidupnya. Dengan mengaplikasikan bagi semua orang percaya peran orang kristen sebagai garam dunia yang berdampak dimanapun berada dan kapanpun karena apa yang dilakukan dalam ahidupnya mempermulikan Tuhan.

${ }^{54}$ Olaf Herbert Schumann, Agama-Agama Kekerasan Dan Perdamaian (Jakarta: BPK Gunung Mulia, 2011), 266.

${ }^{55}$ Harls Evan Rianto Siahaan, "Hikmat Sebagai Implikasi Pendidikan Kristiani: Refleksi 1 Raja-Raja 3:1-15," DUNAMIS: Jurnal Penelitian Teologi dan Pendidikan Kristiani (2016); Henry's Matthew, "Matthew Henry Commentary On Whole Bible."

${ }^{56}$ Siahaan, "Hikmat Sebagai Implikasi Pendidikan Kristiani: Refleksi 1 Raja-Raja 3:1-15." 
Yonatan, Reni, Daniel: Menerapkan Matius 5:13 Terang Garam Dunia di Tengah Era Disrupsi

\section{Daftar Pustaka}

Arifianto, Yonatan Alex, and Asih sumiwi Rachmani. "Peran Roh Kudus Dalam Menuntun Orang Percaya Kepada Seluruh Kebenaran Berdasarkan Yohanes 16 : 13.” Jurnal Diegesis (2020).

Barclay, William. Pemahaman Alkitab Stiap Hari Injil Matius Pasal 1-10. Jakarta: BPK Gunung Mulia, 2008.

Bashori, Khoiruddin. "Pendidikan Politik Di Era Disrupsi." Sukma: Jurnal Pendidikan (2018).

Bergant, Dianne, and Robert J. Karris. Tafsir Alkitab Perjanjian Baru. Yogyakarta: kanisius, 2002.

Erman S. Saragih. "SOTERIOLOGI HYPERGRACE DALAM PERSPEKTIF TEOLOGI MARTIN LUTHER DAN ALKITAB.” Teologi Cultivation (2017).

Ginting, Christine Fuceria. "Konsep Kepemimpinan Penggembalaan Berdasarkan 1 Timotius Dan Aplikasinya Terhadap Pertumbuhan Rohani Jemaat." PNEUSTOS: Jurnal Teologi Pantekosta (2018).

Halim, Makmur. Model-Model Penginjilan Yesus: Suatu Penerapan Masa Kini. Malang: gandum mas, 2003.

Hartopo, Yohanes Adrie. "Doktrin Sola Scriptura ." Veritas : Jurnal Teologi dan Pelayanan (2002).

Henry's Matthew. "Matthew Henry Commentary On Whole Bible."

Kasali, Rhenald. Self Disruption. Jakarta: Mizan Anggota IKAPI, 2018.

Knitter, Paul F. Pengantar Teologi Agama-Agama. Yogyakarta: penerbit Kanisius, 2012.

Kooij, Rijnardus A. van, Sri Agus Patnaningsih, and Yam'ah Tsalatsa. Menguak Fakta, Manata Karya Nyata”: Sumbangan Teologi Praktis Dalam Pencarian Model Pembangunan Jemaat Kontekstual. Jakarta: BPK Gunung Mulia, 2007.

Leks, Stefan. Tafsir Injil Matius. Yogyakarta: penerbit Kanisius, 2003.

Lumoindong, Gilbert. Karakter Warga Gereja,. Jakarta: Light Publishing, 2010.

Manurung, Kosma. “Ketubim Dan Nubuat.” Pengarah: Jurnal Teologi Kristen (2020).

_. "Taurat Dan Nubuat Palsu: Kajian Sudut Pandang Taurat Terhadap Nubuat Palsu." Jurnal Teologi Berita Hidup (2020).

Martasudjita, Emanuel. Sakramen-Sakramen Gereja: Tinjuan Teol, Liturgis, Pastoral. Yogyakarta: penerbit Kanisius, 2003.

Mimery, Nehemia. Komentar Praktis Injil Sinoptik. Jakarta: Mimery Press, 1999.

Muliawaty, Lia. "PELUANG DAN TANTANGAN SUMBER DAYA MANUSIA DI ERA DISRUPSI." Kebijakan : Jurnal Ilmu Administrasi (2019).

Nixon, R.E. Matius Dalam Tafsiran Alkitab Masa Kini. Edited by H.P. Nasution. Voleme 3. Jakarta: Yayasan Komunikasi Bina Kasih/OMF, 1999.

Objantoro, Enggar. "Religious Pluralism And Christian Responses." Evangelikal: Jurnal Teologi Injili dan Pembinaan Warga Jemaat (2018).

Panjaitan, Firman, and Marthin Steven Lumingkewas. "Ibadah Jemaat Kristen Kontemporer Abad 21 Dan Tinjauan Kritis-Liturgis.” FIDEI: Jurnal Teologi Sistematika dan Praktika (2019).

Rantung Djoys Anneke. Pendidikan Agama Kristen Dalam Kehidupan Masyarakat Majemuk. Yogyakarta: Lintang Rasi Aksara Books, 2017.

Ronda, Daniel. "Kepemimpinan Kristen Di Era Disrupsi Teknologi." Evangelikal: Jurnal Teologi Injili dan Pembinaan Warga Jemaat (2019). 
Sairwona, Wellem. "KAJIAN TEOLOGIS PENYAMPAIAN FIRMAN TUHAN DAN PENGARUHNYA BAGI PERTUMBUHAN IMAN JEMAAT.” Jurnal Pendidikan Agama Kristen (2017).

Schumann, Olaf Herbert. Agama-Agama Kekerasan Dan Perdamaian. Jakarta: BPK Gunung Mulia, 2011.

Siahaan, Harls Evan Rianto. "Hikmat Sebagai Implikasi Pendidikan Kristiani: Refleksi 1 Raja-Raja 3:1-15.” DUNAMIS: Jurnal Penelitian Teologi dan Pendidikan Kristiani (2016).

Singgih, Emanuel Gerrit. Bergereja, Berteologi Dan Bermasyarakat. Yogyakarta: Taman Pustaka Kristen, 2007.

Singgih, Emmanuel Gerrit. Mengantisipasi Masa Depan: Berteologi Dalam Konteks Di Awal Milenium III. Jakarta: BPK Gunung Mulia, 2004.

Tamaweol, Roy D. "IMAN KRISTEN DAN GERAKAN KHARISMATIK." Jurnal Teologi Educatio Christi (2017).

Tim Penulis KAMBIUM. Berbuah Dalam Kristus: Pemuridan Melalui Waktu Teduh. Yogyakarta: Yayasan Gloria, 2015.

Witness Lee. Pelajaran Hayat Lukas (2). Surabaya: Yayasan Perpustakaan Injil Indonesia (Yasperin), 2019.

Wright, Christopher J. H. Misi Umat Allah,. Jakarta: Literatur Perkantas, 2011.

Wulansasi, Ajeng, and Ahmad Aji Jauhari Ma'mun. "KEPEMIMPINAN PENDIDIKAN: MENGHADAPI DISRUPSI DAN VUCA DI MASA DEPAN." MANAGERE : Indonesian Journal of Educational Management 1 (2019): 51-75.

Yohanes, Andi. Berjumpa Dengan Dia Yang Bangkit. Jakarta: BPK Gunung Mulia, 2007. Zaluchu, Sonny Eli. "Strategi Penelitian Kualitatif Dan Kuantitatif Di Dalam Penelitian Agama." Evangelikal: Jurnal Teologi Injili dan Pembinaan Warga Jemaat 4, no. 1 (2020): 28-38. 